\title{
Chitin Synthase, a Fungal Glycosyltrans- ferase that Is a Valuable Antifungal Target
}

\author{
Jean-Bernard Behr*
}

\begin{abstract}
During the last 30 past years, more life-threatening fungal infections have appeared due to the increasing frequency of patients with weakened immune systems. Inhibition of fungal enzymes involved in the biosynthesis of sterols is considered to be a safe and effective option for antifungal therapy. However, the intensive use of sterol-biosynthesis inhibitors for years has resulted in resistance development. Consequently, the search for alternative therapeutics must be intensified. In this context, the biosynthesis of chitin, an essential component of the fungal cell wall that is absent in mammalian cells, was envisioned as a safe and selective therapeutic target. We present here recent successes in the inhibition of chitin synthase, the enzyme involved in the last step of the biosynthesis of chitin.
\end{abstract}

Keywords: Antifungal · Glycosyltransferase $\cdot$ Iminosugars $\cdot$ Inhibition $\cdot$ Nikkomycin

\section{Introduction}

Fungal cells are protected from the external environment by the cell wall, an initial barrier made mostly of carbohydrates. ${ }^{[1]}$ This cell wall is essential for the maintenance of cell shape, prevention of lysis and regulation of biochemical exchange with the environment. [2] The composition of mers: glucans, mannoproteins and chitin. ${ }^{[3]}$ Chitin is a linear polysaccharide composed of 2-acetamido-2-deoxy-D-glucose (GlcNAc) units joined through $\beta-(1,4)$ glycosidic linkages (Fig. 1). ${ }^{[4]}$ It is indispensable for fungal survival. Cells in which the formation of chitin is disrupted are affected by osmotic sensitivity, abnormal morphology and growth arrest. ${ }^{[5]}$ Since chitin is absent from vertebrates, inhibition of its biosynthesis has been considered as a safe and selective option for the development of antifungal agents. ${ }^{[6]}$ the cell walls is made up of three biopoly-

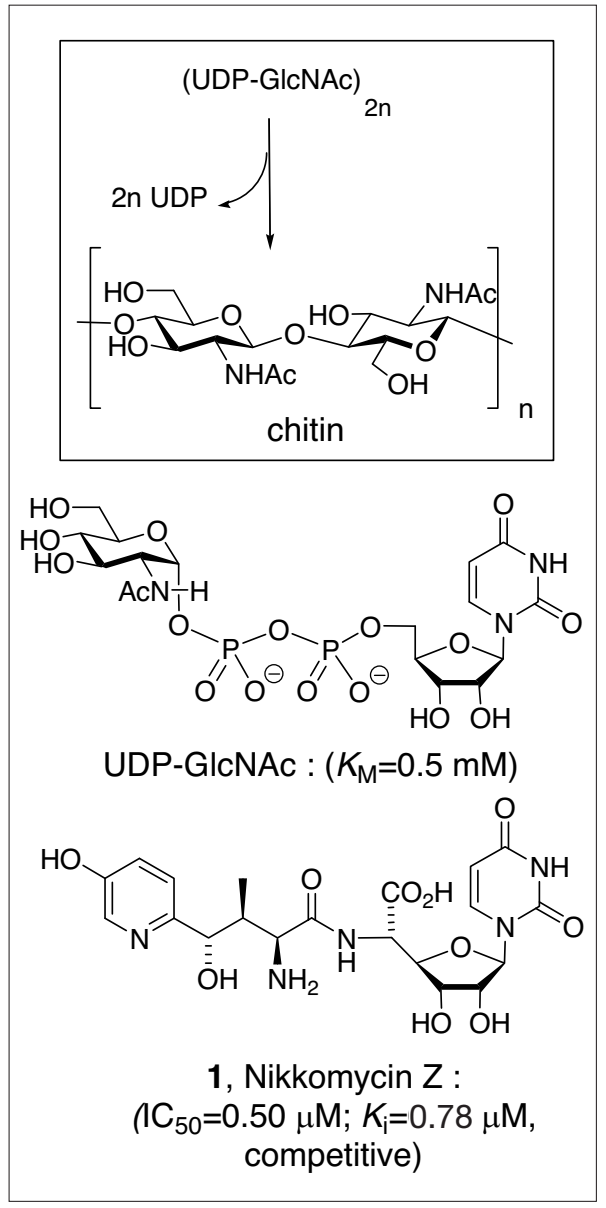

Fig. 1. Biosynthesis of chitin from UDPGlcNAc.

Formation of chitin is a highly complex

${ }^{*}$ Correspondence: Dr. J.-B. Behr

Université de Reims Champagne-Ardenne Institut de Chimie Moléculaire de Reims CNRS UMR 6229

UFR des Sciences Exactes et Naturelles BP 1039 - 51687 Reims Cedex 2, France.

Tel.: +33 326913238

Fax: +33 326913166

E-mail: jb.behr@univ-reims.fr
UDP-GlcNAc as the obligate substrate. In Saccharomyces cerevisiae, three distinct chitin synthase activities (ScCSI, ScCSII and ScCSIII) have been described, which differ in function, localization, cation specificity, optimum $\mathrm{pH}$ and even sensitivity to inhibitors. ${ }^{[8]}$ The chemical transformation catalyzed by CS can be seen as a repetitive transfer of GlcNac residues from the activated donor UDP-GlcNAc to the growing chitin chain (Fig. 1), with concomitant release of UDP.

Though all enzymes of the chitin biosynthetic pathway could serve as targets in antifungal drug design, most studies concerned chitin synthase, ${ }^{[9]}$ by analogy with what is found in Nature. Indeed, the 'natural' control of chitin metabolism is achieved by the antifungal antibiotics nikkomycins and polyoxins that specifically inhibit chitin synthase with $K$ values in the low micromolar range. ${ }^{[10]}$ The structural resemblance of these peptidyl nucleosides with UDP-GlcNAc has been pointed out to explain their high potency to bind to the catalytic site of chitin synthase. Nikkomycin $\mathrm{Z}(\mathbf{1}, \mathrm{NiZ})$, one of the most potent CS inhibitors $\left(K_{\mathrm{i}}=0.78 \mu \mathrm{M}\right){ }^{[11]}$ showed good in vitro activity against a number of pathogenic fungi (MIC $=12 \mu \mathrm{g} / \mathrm{mL}$ for Candida albicans, $\mathrm{MIC}=0.78 \mu \mathrm{g} / \mathrm{mL}$ for Blastomyces dermatidis) and to date, this compound is the only CS inhibitor that underwent clinical trials. ${ }^{[12]}$ However, despite excellent in vitro results, nikkomycins and polyoxins display restricted ability to stop fungal growth in vivo due to either inefficient transport or degradation before reaching the target enzyme. The search for new CS inhibitors with enhanced antifungal activity follow three strategies: i) identification of new inhibitors from natural sources by screening programs, ${ }^{[13]}$ ii) 
inhibition based on substrate analogues using $\mathbf{1}$ as the lead compound or iii) inhibition based on mechanism with the design of transition-state mimetics or bisubstrate analogues. Recent results following the two last options are discussed here.

\section{The Development of Synthetic NiZ Analogues}

The design of analogues that could function as inhibitors of chitin synthase focused on structural features of either the natural substrate UDP-GlcNAc or the NiZ core and aimed to address the issues limiting in vivo activity: hydrolytic degradation and poor uptake. The most simple nonhydrolyzable analogue of UDP-GlcNAc was prepared by the Finney ${ }^{[14]}$ and Kirk ${ }^{[15]}$ groups and features a methylene in place of the glycosidic oxygen (compound 2, Fig. 2). Phosphonate $\mathbf{2}$ was a very weak inhibitor of chitin synthase $\left(K_{\mathrm{i}}>10 \mathrm{mM}\right)$ having much lower affinity for the active site than UDP-GlcNAc itself $\left(K_{\mathrm{M}}=0.5\right.$ $\mathrm{mM})$. Interestingly, the replacement of the sugar residue in $\mathbf{2}$ by a hetaryl moiety (compound 3 ) restored the inhibitory potency $\left(\mathrm{IC}_{50}=0.82 \mathrm{mM}\right) .{ }^{[16]}$ The quinoleine group certainly assumes complementarity between the hydrophobicity of CS and its inhibitors, as exemplified by NiZ. Using 3 as a template, we prepared analogues featuring other nonhydrolizable phosphate mimics such as tartrate, malonate or monosaccharidic residues (Fig. 3).[17] Whereas quinoleine-malonate $4\left(\mathrm{IC}_{50}=2.9 \mathrm{mM}\right)$ or tartrate $5\left(\mathrm{IC}_{50}=2.0 \mathrm{mM}, K_{\mathrm{i}}=0.79 \mathrm{mM}\right.$, competitive) display weaker activity than the corresponding phosphonate, the inhibition potencies of monosaccharidic derivatives $\mathbf{6}$ depend on the substitution pattern $\left(\mathrm{IC}_{50}=0.80-3.2 \mathrm{mM}\right)$. The 1,3 substituted glucose nucleoside $\mathbf{6 a}$ was the most active of the series, which displayed $K_{\mathrm{i}}=0.25$ $\mathrm{mM}$ with a competitive inhibition pattern.

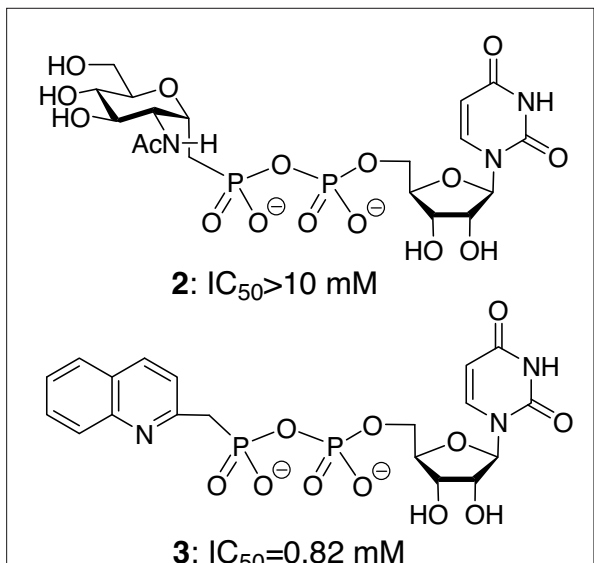

Fig. 2. Inhibition of chitin synthase by substrate analogues 2 and 3.

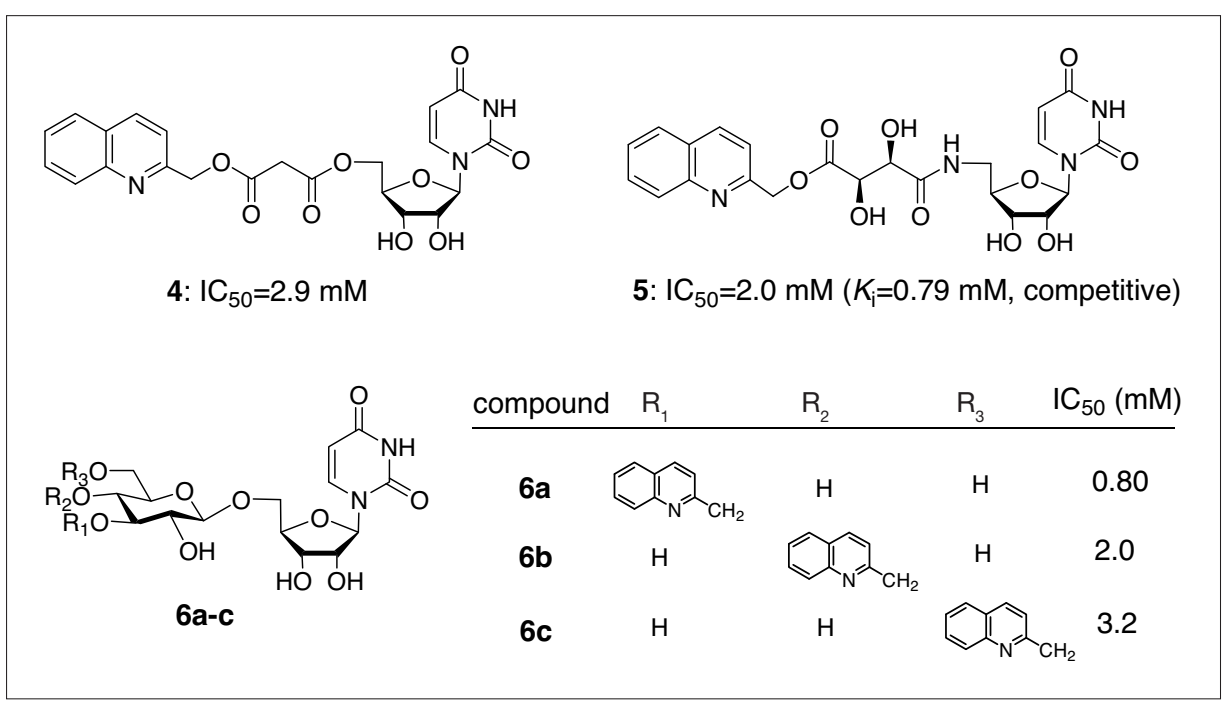

Fig. 3. Inhibition of chitin synthase by hetaryl nucleosides 4-6.

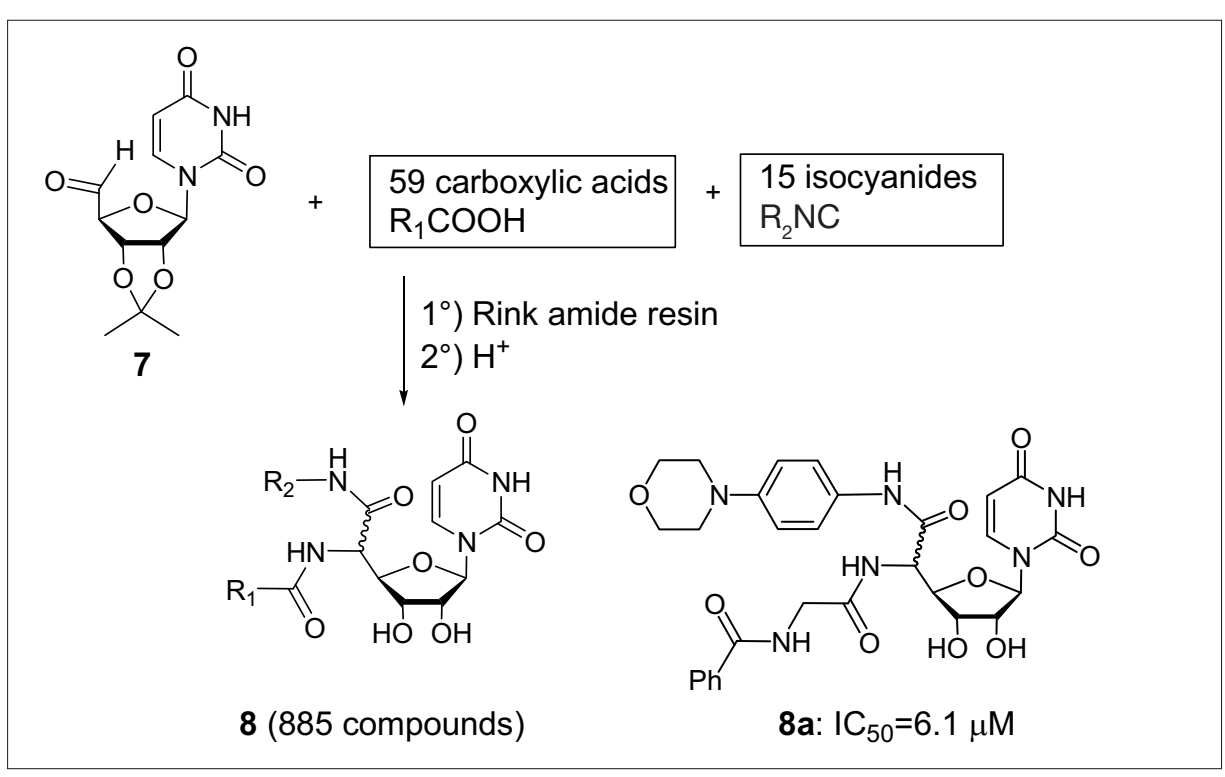

Scheme 1. Combinatorial synthesis of $\mathrm{NiZ}$ analogues 8.

Surprisingly, the replacement of the quinoleine moiety in the structure of $\mathbf{4}$ or $\mathbf{5}$ by a hydroxypyridine to resemble NiZ did not improve the binding interactions. ${ }^{[17]}$

A combinatorial synthesis of a large series of peptidyl-nucleosides has been described for the construction of library of NiZ analogues. The Ugi condensation of the uridinyl aldehyde 7 with a combination of various carboxylic acids and isocyanides gave 885 bis-amides of type 8 (Scheme 1). ${ }^{[18]}$ Some hits were identified, which were as active as NiZ against CS from Candida albicans, compound $\mathbf{8 a}$ $\left(\mathrm{IC}_{50}=6.1 \mu \mathrm{M}\right)$ being the most promising candidate for therapeutic application. Based on a receptor site model calculation for NiZ, a study by Obi and coworkers aimed at designing a new series of $\mathrm{NiZ}$ analogues with simplified chemical structure. ${ }^{[19]}$ Molecular modeling has stressed out the existence of a binding pocket with strong hydrophobic character, close to the catalytic site. Thus, 23 novel NiZ analogues 9 with aromatic groups at the $\beta$-position were prepared, some of them displayed strong anti-CS activity (selected data in Scheme 2).

A library of 1,4-disubstituted-1,2,3triazolyluridine derivatives was realized recently using $\mathrm{Cu}(\mathrm{I})$-catalyzed 1,3-dipolar cycloaddition of the azido-uridine $\mathbf{1 0}$ with propargylated aromatics (Scheme 3).[20] The design of these targets was mainly based on the replacement of the peptide linker of NiZ with a triazole moiety. Chitin synthase activity was evaluated for Benjaminiella poitrasii cells. Surprisingly, the isopropylidene-protected nucleosides $\mathbf{1 1}$ displayed potent anti-CS activity (80-95\% inhibition at $4 \mu \mathrm{g} / \mathrm{mL}$ ) and good antifungal potency against human and plant pathogens. In an analogous approach, Plant and coworkers designed unprecedented $\mathrm{NiZ}$ 


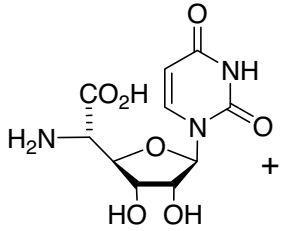<smiles>[Y]C(N)C(=O)O</smiles><smiles>[C]#C</smiles>

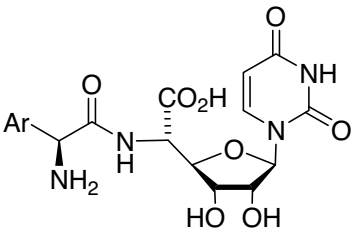

9a-d

i: N-hydroxysuccinimide/DCC, 16-60\%; ii: TFA, then Dowex XFS-43279, 19-98\%.

\begin{tabular}{|c|c|c|c|}
\hline compound & $\mathrm{Ar}$ & $\begin{array}{l}\% \text { inhibition at } \\
100 \mu \mathrm{g} / \mathrm{mL}\end{array}$ & $\mathrm{IC}_{50}(\mu \mathrm{g} / \mathrm{mL})$ \\
\hline $\mathrm{NiZ}$ & & - & 0.4 \\
\hline $9 a$ & & 96 & 6.4 \\
\hline $9 b$ & & 99 & 4.7 \\
\hline $9 c$ & & 99 & 0.3 \\
\hline 9d & & 34 & - \\
\hline
\end{tabular}

Scheme 2. Synthesis and chitin synthase inhibition potencies of $\mathrm{NiZ}$ analogues 9.<smiles>CC1(C)OC2OC(CN)C(O2)C1n1ccc(=O)[nH]c1=O</smiles>

10<smiles>C#CCOc1ccccc1</smiles>

11 (14 examples) i: $\mathrm{CuSO}_{4}-5 \mathrm{H}_{2} \mathrm{O}$, sodium ascorbate, $t-\mathrm{BuOH} / \mathrm{H}_{2} \mathrm{O}, 28^{\circ} \mathrm{C}$.

compound $\quad \mathrm{R} \quad \mathrm{CS}(\%$ inhibition yeast growth at $4 \mu \mathrm{g} / \mathrm{mL}) \quad(\%$ inhibition at $4 \mathrm{mg} / \mathrm{mL})$

(11a

Scheme 3. Synthesis and biological evaluation of triazoles 11. analogues bearing an isoxazole ring as the phosphate surrogate. ${ }^{[21]}$ Unfortunately, their inhibitory activities toward CS have not been reported yet.

\section{The Design of Mechanism-based Inhibitors}

Like other polymerizing transferases, chitin synthase is an integral membrane protein for which little information is available concerning its structure and mode of action. However, by analogy with other glycosyltransferases or with glycosidases, a direct $\mathrm{S}_{\mathrm{v}} 2$-type transfer seems to be a reasonable hypothesis. It requires the intervention of a metallic cation $\left(\mathrm{Mg}^{2+}\right.$, $\left.\mathrm{Mn}^{2+}, \mathrm{Ni}^{2+}\right)$ as an activating Lewis acid (Fig. 4). ${ }^{[22]}$

The design of transition state mimetics or bisubstrate analogues has been applied with success to glycosyltransferases in the gluco, galacto or fuco series. ${ }^{[23]}$ The goal is to simulate in a stable mimetic, most functionalities (charge, shape, polarity) of one or both substrates in the transition state of the enzymatic reaction. Since the topology of the active site has evolved to best complement the structure of the reaction transition state, such an analogue should largely surpass a conventional substrate or a substrate mimic in affinity. ${ }^{[24]}$ In our group several of transition state mimics for chitin synthase were designed that incorporate single or multiple features of UDP-GlcNAc and/ or chitin under formation (Fig. 4). On this basis, we synthesized polyhydroxypyrrolidines 12a,b,,${ }^{[25,26]}$ difluoromethyl-phosphonoiminosugar $\mathbf{1 3}^{[27]}$ pseudodisaccharides $\mathbf{1 4 a}, \mathbf{b}$ and pyrrolizidine $15 .{ }^{[28]}$ The five-membered ring iminosugar mimics the half chair conformation and the charge (through protonation at physiological $\mathrm{pH}$ ) of the glycosyl cation, whereas the phosphonate moiety and the additional GlcNAc residue promote supplementary binding interactions by mimicking either the pyrophosphate group or the growing chitin chain. Iminosugar $\mathbf{1 2 b}$ and phosphonoiminosugar $\mathbf{1 3}$ are weak inhibitors of CS, with $\mathrm{IC}_{50} \mathrm{~s}$ above $2.6 \mathrm{mM}$. Surprisingly, the presence of a supplementary GlcNAc residue, expected to mimic the acceptor of the glycosyltransfer reaction, led to a reduction of the inhibition of the enzyme $\left(\mathrm{IC}_{50}=5.5\right.$ $\mathrm{mM}$ for $14 \mathrm{a}$, whereas $\mathrm{IC}_{50}=2.6 \mathrm{mM}$ for the corresponding pyrrolidinol 12b). Interestingly, compound 12a, an iminosugar found in Nature, is significantly more effective $\left(\mathrm{IC}_{50}=65 \mu \mathrm{M}, K_{\mathrm{i}}=38 \mu \mathrm{M}\right){ }^{[29]}$ In spite of minimal structural complexity, iminosugar 12a was as active as more elaborated natural or synthetic CS inhibitors. It is worth noting that the stereochemical integrity of 12a is essential for binding since the $C(2)$ epimer $\mathbf{1 2 b}$ exhibited only weak inhibition 


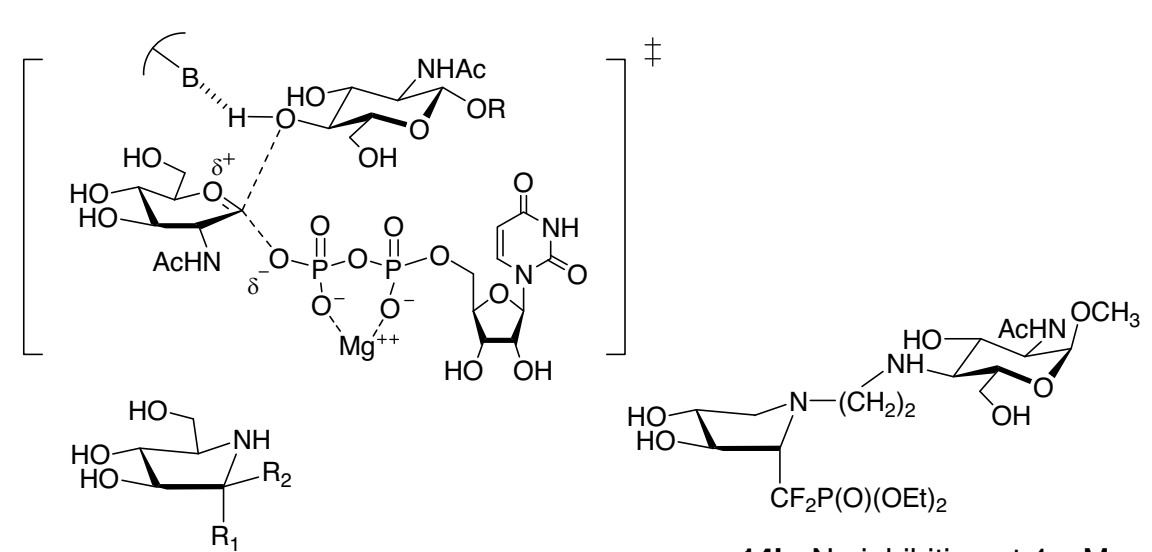

12a: $\mathrm{R}_{1}=\left(\mathrm{CH}_{2}\right)_{2} \mathrm{OH}, \mathrm{R}_{2}=\mathrm{H}, \mathrm{IC}_{50}=0.065 \mathrm{mM}$

12b: $\mathrm{R}_{1}=\mathrm{H}, \mathrm{R}_{2}=\left(\mathrm{CH}_{2}\right)_{2} \mathrm{OH}, \mathrm{IC}_{50}=2.6 \mathrm{mM}$

13: $R_{1}=C F_{2} P(O)(O E t) O H, R_{2}=H, I_{50}=39 \mathrm{mM}$

14a: $\mathrm{R}_{1}=\mathrm{H}, \mathrm{R}_{2}={ }_{\left(\mathrm{CH}_{2}\right)_{2} \mathrm{NHO}} \overbrace{\mathrm{OH}}^{\mathrm{AcHN}}, \mathrm{IC}_{50}=5.5 \mathrm{mM} \quad 15: \mathrm{IC}_{50}=0.82 \mathrm{mM}$

Fig. 4. Design of transition-state analogues for chitin synthase.

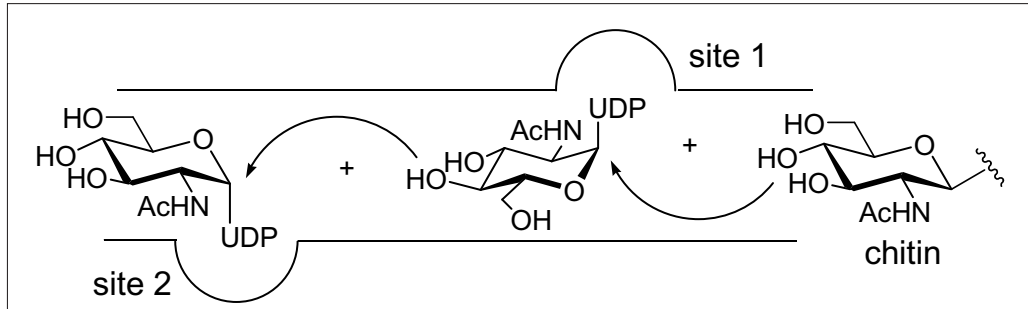<smiles>CC(C)(COC(=O)NCC1OC2OC1C(O)C2O)OC(=O)NCC1OC2C(O)C1OC2n1ccc(=O)[nH]c1=O</smiles>

16: $I C_{50}=1.1 \mathrm{mM}$<smiles>O=C(NCC1OC2OC(C1O)C(O)C2O)C1OC(n2ccc(=O)[nH]c2=O)C(O)C1O</smiles>

17: $35 \%$ inibition at $1 \mathrm{mM}$<smiles>CC1(C)COC(=O)NCC2OC(OC(C)(C)CO1)C(O)C(n1ccc(=O)[nH]c1=O)O2</smiles>

18: $\mathrm{IC}_{50}=11.8 \mathrm{mM}$

(6\% inhibition at $1 \mathrm{mM})$

Fig. 5. Design of dimeric inhibitors for chitin synthase.

towards chitin synthase.

New polyhydroxy-pyrrolizidines were designed next as constrained analogues of 6-deoxy-homoDMDP 12a, to improve binding through pre-orientation of the essential hydroxyethyl substituent. Enzymatic assays revealed that 7-deoxycasuarine the range 4.3-18.9 mM.[28] other groups. [30] The Finney group has focused on the design of dimeric analogues that assume a two-active-site mechanism. Indeed, the opposed orientation of two adjacent monosaccharidic units in the structure of chitin (each sugar is rotated $\approx 180^{\circ}$ relative to the preceding one in the chain) have suggested that a processive transferase such as chitin synthase operates by transferring two sugar units simultaneously with alternating up/down configuration. One possible explanation is that CS or an associated protein pre-assembles the required disaccharide donor (UDP-chitobiose), allowing extension by two residues at a time. However, this hypothesis was excluded by running experiments with radiolabelled UDP-chitobiose. ${ }^{[31]}$ An alternative proposal is that CS has two active sites in close proximity, one for each sugar orientation (Fig. 5). ${ }^{[32]}$ To probe this hypothesis, Finney and coworkers prepared a series of dimeric inhibitors that contain two uridinyl moieties linked by an aliphatic tether. ${ }^{[33]}$ Though the compounds displayed weak inhibition potencies it appeared clearly that bivalent inhibitors such as $\mathbf{1 6}$ or $\mathbf{1 7}$ displayed activity approximately 10 -fold higher than that of the corresponding monomer $\mathbf{1 8}$, providing some evidence for the two-active-site mechanism.

\section{Conclusion}

Chitin synthase, the enzyme that converts UDP-GlcNAc to chitin, is a member of a class of enzymes known as polymerizing (or processive) glycosyltransferases. Since chitin is an essential component of the fungal cell wall, that is absent in mammals, CS has been recognized as a promising antifungal target. The natural peptidyl nucleosides nikkomycins and polyoxins are competitive chitin synthase inhibitors with $K_{\mathrm{i}} \mathrm{s}$ in the micromolar range, which display strong in vitro antifungal activity. The search for new CS inhibitors allowed identification of candidates with excellent affinities for CS. To date, no detailed information is available on the structure of CS or its accurate mechanism of action, impeding the rational design of more effective inhibitors. Alternatively, the design of future inhibitors should explore new mechanistic proposals or should focus on identifying new functional groups that improve binding with the enzyme.

Received: August 10, 2010

15 was the best inhibitor of the series $\left(\mathrm{IC}_{50}\right.$ $=820 \mu \mathrm{M}$ ) displaying a non-competitive inhibition pattern, whereas the diastereoisomeric pyrrolizidines had $\mathrm{IC}_{50}$ values in

Attempts to prepare mechanism-based inhibitors of CS have been reported by
[1] F. M. Klis, A. Boorsma, P. W. J. De Groot, Yeast 2006, $23,185$.

[2] J.-P. Latgé, Molecul. Microbiol. 2007, 66, 279. Robbins, E. Cabib, J. Biol. Chem. 1995, 270, 1170.
[3] R. Kollar, E. Petrakova, G. Ashwell, P. W. 
[4] R. Minke, J. Blackwell, J. Mol. Biol. 1978, 120, 167.

[5] E. Cabib, S. Roberts, B. Bowers, Annu. Rev. Biochem. 1982, 51, 763 .

[6] J. Ruiz-Herrera, G. San-Blas, Curr. Drug Targets Infect. Disord. 2003, 3, 77; D. M. Rast R. A. Merz, A. Jeanguenat, E. Mösinger, Advan. Chitin Sci. 2000, 4, 479 .

[7] C. E. Bulawa, Ann. Rev. Microbiol. 1993, 47, 505; J. A. Shaw, P. C. Mol, B. Bowers, S. J. Silverman, M. H. Valdiviesco, A. Duran, E. Cabib, J. Cell Biol. 1991, 114, 111

[8] W.-J. Choi, E. Cabib, Anal. Biochem. 1994, 219, 368; E. Cabib, Antimicrob. Agents Chemother 1991, 35, 195; J. P. Martinez, D. Gozalbo, Microb. Sem. 1994, 10, 239

[9] J.-B. Behr, Curr. Med. Chem. (Anti Infective Agents) 2003, 2, 173.

[10] M. Winn, R. J. M. Goss, K. Kimura, T. D. H. Bugg, Nat. Prod. Rep. 2010, 27, 279.

[11] J.-B. Behr, I. Gautier-Lefebvre, C. MvondoEvina, G. Guillerm, N. S. Ryder, J. Enz. Inhib. 2001, 16, 107.

[12] J. R. Graybill, L. K. Najvar, R. Bocanegra, R. F. Hector, M. F. Luther, Antimicrob. Agents Chemother. 1998, 42, 2371; R. K. Li, M. G. Rinaldi, Antimicrob. Agents Chemother. 1999, 43, 1401; D. A. Stevens, Antimicrob. Agents Chemother. 2000, 44, 2547.

[13] For recent reports concerning the screening of natural products against chitin synthase, see: $\mathrm{T}$ H. Kang, E. I. Hwang, B. S. Yun, K. D. Park, B. M. Kwon, C. S. Shin, S. U. Kim, Biol. Pharm. Bull. 2007, 30, 598; T. H. Kang, E. I. Hwang, B. S. Yun, C. S. Shin, S. U. Kim, Biol. Pharm Bull. 2008, 31, 755; N. H. Yim, E. I. Hwang, B S. Yun, K. D. Park, J. S. Moon, S. H. Lee, N. D. Sung, S. U. Kim, Biol. Pharm. Bull. 2008, 31 1041; S. Lee, J. N. Kim, E. Kim, M.-S. Kim, H. K. Lee, Bull. Korean Chem. Soc. 2009, 30, 3092.

[14] R. Chang, T.-T. Vo, N. S. Finney, Carbohydr. Res. 2006, 341, 1998.

[15] J. Hajduch, G. Nam, E. J. Kim, R. Fröhlich, J. A. Hanover, K. L. Kirk, Carbohydr. Res. 2008, 343, 189.

[16] M. Djebaili, J.-B. Behr, unpublished results.

[17] J.-B. Behr, T. Gourlain, A. Helimi, G. Guillerm, Bioorg. Med. Chem. Lett. 2003, 13, 1713.
[18] A. Suda, A. Ohta, M. Sudoh, T. Tsukuda, N. Shimma, Heterocycles 2001, 55, 1023.

[19] K. Obi, J.-I. Uda, K. Iwase, O. Sugimoto, H. Ebisu, A. Matsuda, Bioorg. Med. Chem. Lett. 2000, 10, 1451 .

[20] P. M. Chaudhary, S. R. Chavan, F. Shirazi, M. Razdan, P. Nimkar, S. P. Maybhate, A. P. Likhite, R. Gonnade, B. M. Hazara, M. V. Deshpande, S. R. Deshpande, Bioorg. Med. Chem. 2009, 17, 2433.

[21] A. Plant, P. Thompson, D. M. Williams, J. Org. Chem. 2008, 73, 3714.

[22] M. L. Sinnott, Chem. Rev. 1990, 90, 1171.

[23] H. Hashimoto, T. Endo, Y. Kajihara, J. Org. Chem. 1997, 62, 1914; S. Takayama, S. J. Chung, Y. Igarashi, Y. Ichikawa, A. Sepp, R. I. Lechler, J. Wu, T. Hayashi, G. Siuzdak, C.-H. Wong, Bioorg. Med. Chem. 1999, 7, 401; Y.-J. Kim, M. Ichikawa, Y. Ichikawa, J. Am. Chem. Soc. 1999, 121, 5829; M. L. Mitchell, F. Tian, L. V. Lee, C.-H. Wong, Angew. Chem. Int. Ed. 2002, 41, 3041; R. Wang, D. H. Steensma, Y. Takaoka, J. W. Yun, T. Kajimoto, C.-H. Wong, Bioorg. Med. Chem. 1997, 5, 661; C. Saotome, Y. Kanie, O. Kanie, C.-H. Wong, Bioorg. Med. Chem. 2000, 8, 2249.

[24] R. Wolfenden, Bioorg. Med. Chem. 1999, 7 , 647.

[25] J.-B. Behr, G. Guillerm, Tetrahedron: Asymm. 2002, 13, 111.

[26] I. Gautier-Lefebvre, J.-B. Behr, G. Guillerm, M. Muzard, Eur. J. Med. Chem. 2005, 1255.

[27] J.-B. Behr, C. Mvondo-Evina, N. Phung, G. Guillerm, J. Chem. Soc., Perkin Trans. 1 1997, 1597.

[28] J.-B. Behr, A. Gainvors-Claisse, A. Belarbi, Nat. Prod. Res. 2006, 20, 1308.

[29] M. Djebaili, J.-B. Behr, J. Enz. Inhib. Med. Chem. 2005, 20, 123.

[30] L. Devel, A. Vidal-Cros, A. Thellend, Tetrahedron Lett. 2000, 41, 299.

[31] R. Chang, A. R. Yeager, N. S. Finney, Org. Biomol. Chem. 2003, 1, 39

[32] I. M. Saxena, R. M. Brown, M. Fèvre, R. A. Geremia, B. Henrissat, J. Bacteriol. 1995, 177, 1419.

[33] A. R. Yeager, N. S. Finney, J. Org. Chem. 2004, 69, 613; A. R. Yeager, N. S. Finney, Bioorg. Med. Chem. 2004, 12, 6451. 